\title{
インドメタシンスプレーの造血幹細胞移植患者におけるロ内炎疼痛に対する効果
}

\author{
中村教子, ${ }^{a}$ 青山隆夫, ${ }^{*}, a$ 柳原良次, ${ }^{a}$ 山田安彦, ${ }^{a}$ 三芳明美, ${ }^{b}$ \\ 神田善伸, ${ }^{c}$ 平井久丸, ${ }^{c}$ 古川稔朗, ${ }^{d}$ 伊賀立二 ${ }^{a}$
}

\section{The Effects of Indomethacin Spray on the Pain of Stomatitis in the Patients for Hematopoietic Stem Cell Transplantation}

\author{
Takako NAKAMURA, ${ }^{a}$ Takao AOYAMA, ${ }^{*, a}$ Yoshitsugu YANAgIHARA, ${ }^{a}$ \\ Yasuhiko YAMADA, ${ }^{a}$ Akemi MIYOSHI, ${ }^{b}$ Yoshinobu KANDA, ${ }^{c}$ \\ Hisamaru HIRAI, ${ }^{c}$ Toshirou FURUKAWA, ${ }^{d}$ and Tatsuji IGA ${ }^{a}$ \\ Departments of Pharmacy, ${ }^{a}$ Nursing, ${ }^{b}$ and Cell Therapy and Transplantation Medicine, ${ }^{c}$ University of \\ Tokyo Hospital, Faculty of Medicine, University of Tokyo, 7-3-1 Hongo, Bunkyo-ku, Tokyo \\ 113-8655, Japan, and Department of Pharmacy, Nihon University Itabashi Hospital, Faculty \\ of Medicine, ${ }^{d}$ 30-1 Ohyaguchikamimachi, Itabashi-ku, Tokyo 173-0032, Japan
}

(Received May 21, 2003; Accepted September 4, 2003)

\begin{abstract}
We studied the effects of $0.25 \%$ indomethacin (IM) spray as an in-hospital preparation on the pain of stomatitis after hematopoietic stem cell transplantation in 9 patients with various types of leukemia by measuring the change in pain and the decrease in morphine dose. Stomatitis above grade 2 (painful erythema, edema, or ulcers but can eat or swallow) appeared in all patients as white blood cell (WBC) counts declined after transplantation, and clockwise hysteresis was observed between WBC counts and the grade of stomatitis. When the patients used IM spray for the pain of stomatitis and were judged the grade of pain using a face scale of five grades $(0-4)$ before and after the use of this spray, the mean grades of pain at the maximal pain during the appearance of stomatitis declined from 3.4 to $1.8(n=5)$. Furthermore, the concurrent intravenous dose of morphine markedly decreased during IM spray use. There was no complaint concerning the taste and convenience of IM spray by patients. The risk of systemic adverse effects was considered relatively low based on the small amounts of IM applied to the mouth mucosa. In conclusion, it is suggested that IM spray is effective for the relief of stomatitis pain in patients who have undergone hematopoietic stem cell transplantation and is a useful preparation for immediate self-medication upon the appearance of stomatitis pain. We considered that the application of IM spray will contribute to the improvement of patient quality of life.
\end{abstract}

Key words_ — indomethacin spray; stomatitis; pain; WBC; morphine; hematopoietic stem cell transplantation

緒言

骨䯣移植や未梢血幹細胞移植などの造血幹細胞移 植の前処置として全身放射線照射や大量化学療法が

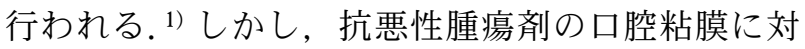
する直接作用と白血球数の減少により, 激しい痛み を伴う口内炎が起きることが知られている. ${ }^{2)}$ 口内 炎発生の予防にはアロプリノールによる含嗽, ${ }^{3)}$ 発 生した口内炎の疼痛の軽減にはリドカインやアズレ ンによる含嗽などが一般的に実施されている. ${ }^{4)}$ 当 院無菌治療部においては造血幹細胞移植患者におけ

${ }^{a}$ ) 東京大学医学部附属病院薬剂部, $\left.{ }^{b}\right)$ 同看護部, ${ }^{c}$ 同無 菌治療部, ${ }^{d}$ 日本大学医学部附属板橋病院薬剂部 e-mail: aoyama-tky@umin.ac.jp
る移植後の口内炎疼痛に対して, モルヒネやブプレ ノルフィンの持続静脈内投与に加えて, スプレー容 器に充填した院内製剤の $0.25 \%$ インドメタシン （IM）水溶液を, 随時, 患者自身が局所噴霧を行つ て疼痛の軽減を図っている。 IM は非ステロイド性 鎮痛薬でありシクロオキシゲナーゼを阻害すること により抗炎症効果を発揮して炎症反応による疼痛を 抑える. ${ }^{5)}$ IM スプレーの効果については, Shiratsuchi らが固形癌患者の化学療法後の口内炎疼痛に 対しての有効性を報告しているが, ${ }^{6}$ 造血幹細胞移 植後の口内炎疼痛に対する IM スプレーの効果につ いての報告はない，そこで, 移植後の患者の口内炎 にIM スプレーを適用し，その有用性について疼痛 の grade の変化とモルヒネの使用量から評価した. 


\section{実 験 の 部}

1. 対象患者 対象患者は平成 12 年 4 月-13 年 12 月までの当院無菌治療部に入室した造血幹細 胞移植患者 9 名とした. 9 名の患者の詳細を Table 1 に示した。患者は男性 6 名, 女性 3 名, 平均年齢 $41.1 \pm 10.9$ 歳 (28-54 歳), 疾患は, 急性骨髄性白 血病 4 名, 急性リンパ性白血病 1 名, 慢性骨髄性白 血病 2 名, 骨䯣異形成症候群 1 名, 非ホジキンリン パ腫 1 名であった。移植の種類は骨髄移植 7 名, 末 梢血幹細胞移植 2 名で，前処置は，シクロホスファ ミド $(\mathrm{CY})+$ 全身放射線照射（TBI）併用 3 名, $\mathrm{CY}+$ エトポシド $+\mathrm{TBI}$ 併用 1 名, $\mathrm{CY}+$ ブスルファ ン併用 4 名, $\mathrm{CY}+$ シタラビン $+\mathrm{TBI}$ 併用 1 名であ つた。モルヒネ使用量を比較するための IM スプ レーを使用していない移植患者群は，平成 11 年 10 月一 14 年 3 月の入室患者 10 名とした.

2. IM スプレーの調製方法 IM スプレーに は， $0.25 \%$ IM 溶液を用いた。これは，従来，院内 製剂として去痰に使用されている $1.25 \%$ IM 吸入 液7)（IM 原液）を Shiratsuchi ら6) が希釈して口内 炎疼痛に用いたものと同じ溶液である。IM 原液は,

IM (ICN Biomedicals, Lot. 6105A) 1.25 g (0.0035M) を $0.2 \mathrm{M} \mathrm{KH}_{2} \mathrm{PO}_{4}: 0.2 \mathrm{M} \mathrm{NaOH}=1: 1$ の溶液 $(\mathrm{pH}$ 約 8.1） 約 $70 \mathrm{~mL}$ に分散させてから， $0.2 \mathrm{M} \mathrm{NaOH}$

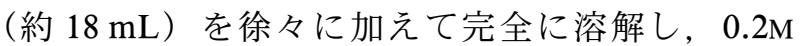
$\mathrm{KH}_{2} \mathrm{PO}_{4}$ を加えて pH 7.4 に調整した後, 滅菌精製 水で全量を $100 \mathrm{~mL}$ として製した（Fig. 1 (a))。実 際に患者に使用した溶液は, IM 原液 $20 \mathrm{~mL}$ に甘味 料のキシリトールを $5 \mathrm{~g}$ ，粘稠性を持たせるために
滅菌グリセリンを $16 \mathrm{ml}$ 加え, 全量を滅菌精製水で $100 \mathrm{~mL}$ に希釈（5 倍希釈）したものを，孔径 0.45 $\mu \mathrm{m}$, 直径 $22 \mathrm{~mm}$, セルロースエステル製のメンブ ランフィルター $\left(\right.$ Millex $^{\circledR}-\mathrm{HA}$ ，日本ミリポア）で ろ過して調製し [IM として $0.25 \%$, Fig. 1(b)]，滅 菌済みスプレー容器（ターキー喉用, TU-80, シン トウ化学)に $10 \mathrm{~mL}$ づつ充填して製した(Fig. 1(c)). $0.25 \% \mathrm{IM}$ 溶液の $\mathrm{pH}$ ，浸透圧及び粘度は各々 $\mathrm{pH}$ メーター（東亜電波, HM20E), 浸透圧計（Advanced Instruments, Model 3900) 及び回転粘度計 （東機産業，TV-20L）を用いて測定した。本スプ レ一容器で $0.25 \%$ IM 溶液を噴霧した場合, $10 \mathrm{~mL}$ で 120 噴霧前後であったことから 1 噴霧中のインド メタシンは約 $0.2 \mathrm{mg}$ であった。 グリセリンは日本 薬局方品を高圧蒸気滅菌 $\left(121^{\circ} \mathrm{C}, 20 \mathrm{~min}\right)$ したも のを, キシリトール, $\mathrm{KH}_{2} \mathrm{PO}_{4}$ 及び $\mathrm{NaOH}$ は試薬 特級品を用いた。調製した薬液は，冷暗所に保存 し，使用期間は 1 カ月とした. ${ }^{7)}$

3. 患者への投与と効果の判定全身放射線照 射と大量化学療法の前処置後の移植日に $0.25 \% \mathrm{IM}$ 溶液 $10 \mathrm{~mL}$ をスプレー容器に充填して患者に手渡 し, 移植後の口内炎疼痛時に随時, 噴霧するように 指示した。使用に関しては，患者に対して医師から 本スプレー（以下 IM スプレー）使用の同意を得た 上で，担当薬剂師が使用方法について作成した説明 用シート (Fig. 2) を用いて説明して十分に理解さ せた。 ポイントとしては, 痛みを感じる時に患部に 1 回 1-2 噴霧とし, 多くても $10 \mathrm{~mL}$ を 3,4 日かけ て使用することとした。また，含嗽液（ポビドン ヨード液，アズノール・プロカイン液）を使用する

Table 1. The Profiles of the Patients Used IM Spray for the Pain of Stomatitis after Hematopoietic Stem Cell Transplantation

\begin{tabular}{cccclll}
\hline \hline Patient & Sex & Age & Disease & TBI & \multicolumn{1}{c}{ High-dose chemotherapy } & BMT or PBSCT \\
\hline 1 & M & 21 & CML & Non & BU $180 \mathrm{mg} \times 4$ days, CY $2700 \mathrm{mg} \times 2$ days & BMT \\
2 & M & 28 & ALL & $12 \mathrm{~Gy}$ & VP-16 $1300 \mathrm{mg} \times 2$ days, CY $2600 \mathrm{mg} \times 1$ day & BMT \\
3 & M & 40 & NHL & $12 \mathrm{~Gy}$ & CY $3900 \mathrm{mg} \times 2$ days & BMT \\
4 & M & 46 & AML & Non & BU $272 \mathrm{mg} \times 4$ days, CY $4100 \mathrm{mg} \times 2$ days & BMT \\
5 & M & 47 & AML & $12 \mathrm{~Gy}$ & CY $3800 \mathrm{mg} \times 2$ days, Ara-C $3500 \mathrm{mg} \times 3$ days & BMT \\
6 & M & 54 & MDS & $12 \mathrm{~Gy}$ & CY $2900 \mathrm{mg} \times 2$ days & BMT \\
7 & F & 38 & AML & $12 \mathrm{~Gy}$ & CY $2600 \mathrm{mg} \times 2$ days & BMT \\
8 & F & 43 & AML & Non & BU 216 mg $\times 4$ days, CY $3250 \mathrm{mg} \times 2$ days & PBSCT \\
9 & F & 53 & CML & Non & BU 204 mg $\times 4$ days, CY 3100 mg $\times 2$ days & PBSCT \\
\hline
\end{tabular}

TBI: total body irradiation, AML: acute marrow leukemia, CML: chronic marrow leukemia, NHL: non-Hodgikin's lymphoma, ALL: acute lymphatic leukemia, MDS: myelodysplastic syndrome, BU: busulfan, CY: cyclophosphamide, VP-16: etoposide, Ara-C: cytarabine, BMT: bone marrow transplantation, PBSCT: peripheral blood stem cell transplantation. 
(a) IM 原液 ( $\mathrm{pH} 7.4)$

\begin{tabular}{|c|c|}
\hline インドメタシン & $1.25 \mathrm{~g}$ \\
\hline $0.2 \mathrm{M}$ リン酸緩銜液 & ad. $100 \mathrm{~mL}$ \\
\hline
\end{tabular}

(b) $0.25 \%$ IM 溶液

\begin{tabular}{|cc|}
\hline IM原液 & $20 \mathrm{~mL}$ \\
キシリトール & $5 \mathrm{~g}$ \\
グリセリン & $16 \mathrm{~mL}$ \\
滅菌精製水 & ad. $100 \mathrm{~mL}$ \\
孔径0. $45 \mu \mathrm{m}$ mンブランフィルター \\
(Millex ${ }^{\otimes}$-HA、日本ミリポア) でろ過 \\
保存法 : 冷暗所保存 \\
\hline
\end{tabular}

(c) IM スプレー

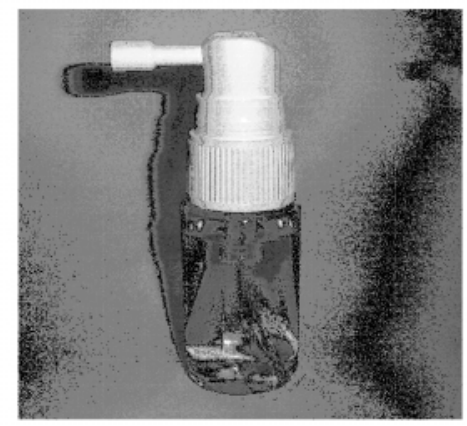

1本 $(10 \mathrm{~mL})=$ インドメタシン25 mg含有

(1噴霧=約 $0.2 \mathrm{mg})$

Fig. 1. Recipe of (a) Indomethacin (IM) Stock Solution (1.25\%), (b) $0.25 \%$ IM Solution, and (c) Photograph of IM Spray

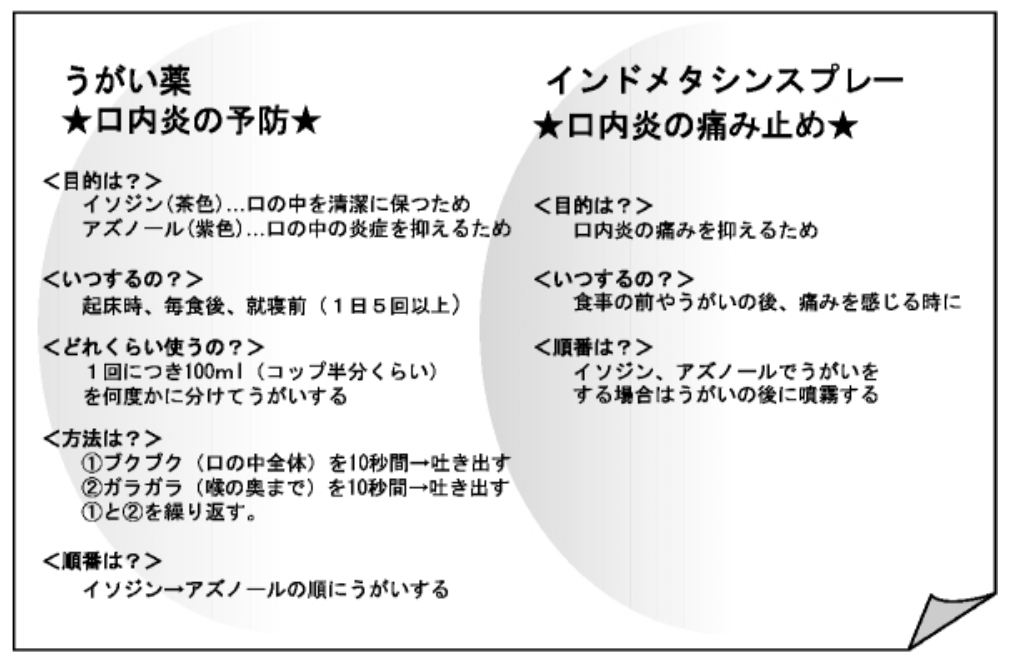

Fig. 2. Sheet for Consultation of Usage of Indomethacin (IM) Spray to Patients for Hematopoietic Blood Stem Cell Transplantation

場合には，含嗽後に噴霧するよう指示した。

なお，塩酸モルヒネの投与は，口内炎疼痛に対す る含嗽液及び IM スプレーによるコントロールが不 十分であると判断された場合に，これらの外用剤と 併用するかたちで， $0.5 \mathrm{mg} / \mathrm{hr}$ の投与量で開始し， 効果を見ながら徐々に増量あるいは減量して疼痛を コントロールした.

移植後の口内炎の程度は JCOG の判定基準（5 段階, grade 0-4, Table 2) 8) を用いて担当看護師が 判定し, 血中の白血球（WBC）数との関係につい て検討した。 IM スプレーの効果は, IM スプレー の使用状況と口内炎疼痛の変化（使用直前と最大効 果発現時の疼痛）を患者自身に記録用紙に記載させ
ることにより判定した。疼痛の程度はがん性疼痛の フェイススケール を皇考にしてロ内炎用の 5 段階 評価のフェイススケール（grade 0-4, Fig. 3）を作 成して用いた。さらに，併用した塩酸モルヒネの持 続静脈内投与量を以前の IM スプレー未使用の患者 群 10 名と比較した。

$$
\text { 結果 }
$$

1. $0.25 \%$ IM 溶液の薬剂学的物性 $\quad 0.25 \%$ IM 溶液の色は透明の黄色であり, $\mathrm{pH}$ は約 7.7 浸透圧 は約 $2000 \mathrm{mOsm} / \mathrm{L}$ であった。ローターコード 20M1，回転速度 $100 \mathrm{rpm}$ の条件で測定した粘度 は, 室温で $5.5 \mathrm{mPas}, 37^{\circ} \mathrm{C}$ で $4.5 \mathrm{mPas}$ であり, 温 
Table 2. JCOG (Japan Clinical Oncology Group) Toxicity Criteria of Stomatitis

\begin{tabular}{ll}
\hline Grade 0 & なし \\
Grade 1 & 軽度の疼痛・紅斑, 鎮痛薬の投与を必要としない \\
Grade 2 & 有痛性紅斑, 軽度の潰瘍・浮腫, 食事摂取可能, 非麻薬性鎮痛薬投与を要する \\
Grade 3 & 中一重度の潰瘍・浮腫, 食事摂取不能, 麻薬の投与を要する \\
Grade 4 & 重篤な潰瘍・浮腫, 気管内挿管を要する
\end{tabular}

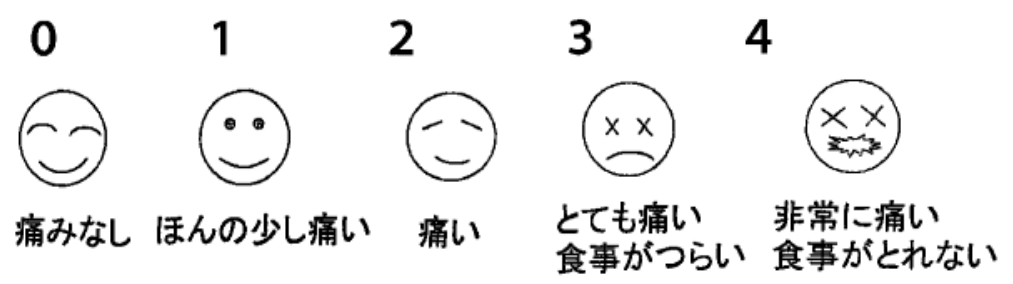

Fig. 3. Face Scale of Pain for Stomatitis Prepared by Modifying Face Scale for Cancer Pain

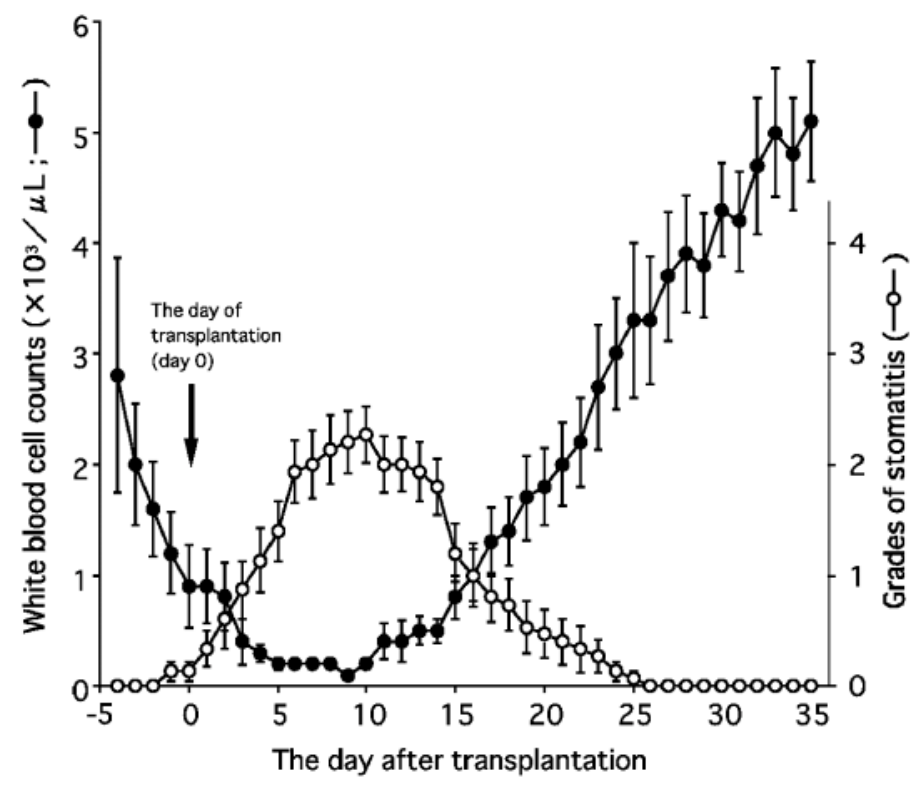

Fig. 4. Time Courses of White Blood Cell (WBC) Counts Cell Transplantation (mean \pm SE, $n=9$ )

度の上昇で若干低下した。

2. 造血幹細胞移植患者における白血球数と口内 炎の程度 Figure 4 に 9 名の患者の移植 4 日前か らの WBC 数と口内炎の grade の経時的変化を示し た. WBC 数は, 移植数日前の処置により急激に低 下し, 移植後 3 日目に $0.5 \times 10^{3} / \mu \mathrm{L}$ 以下となり, そ の後 2 週間目以降から徐々に増加して, 造血幹細胞 の生着が認められた。一方，口内炎の grade は, WBC 数の低下とともに上昇して移植後 7-14 日で 平均值 2-3 の最大に達し, その後徐々に低下して
25 日目にはすべての患者で口内炎は消失した。こ の WBC 数と口内炎の関係を Fig. 5 に示した. 各点 を時系列に結ぶと時計回りのヒステリシスが認めら れ, $\mathrm{WBC}$ 数が $1 \times 10^{3} / \mu \mathrm{L}$ 以下になると口内炎が発 症して, その後 WBC 数の低下に伴って悪化し, $0.5 \times 10^{3} / \mu \mathrm{L}$ 以上に増加すると徐々に回復すること が分かつた。

\section{IM スプレー使用時の口内炎疼痛の変化}

IM スプレー使用時に口内炎疼痛の変化の回答が得 られた患者は 9 名中 5 名であった。効果は噴霧後速 
やかに発現し, その後, 10-15 分に最大効果に達 した．持続時間はデータとしてはとれなかったが, 感触としてはおよそ 4-5 時間であった。 Figure 6 に 1 名の患者（46 歳, 男性）における IM スプレー 噴霧前後の口内炎疼痛の変化の経時的推移を示した. IM スプレー使用前後で, 痛みのスケールでスプ レー前が 2 の場合には 1 へと 1 段階, 3 と 4 の場合

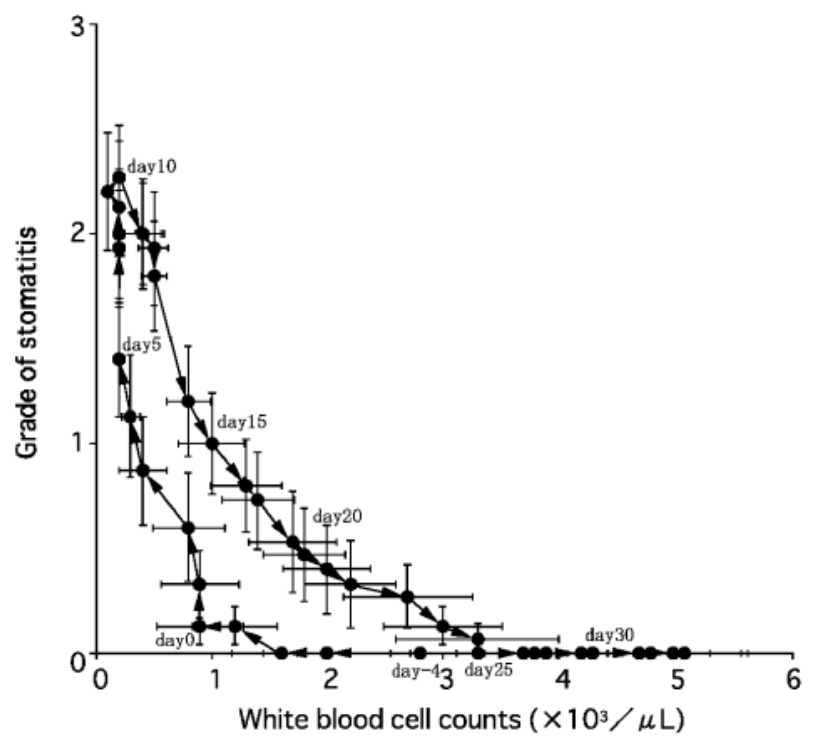

Fig. 5. Relationship of White Blood Cell (WBC) Counts and Grade of Stomatitis in Patients for Hematopoietic Stem Cell Transplantation (mean \pm SE, $n=9$ )
は 1 又は 2 へほぼ 2 段階，疼痛が軽減された。他の 4 名の患者においてもほぼ同様な傾向が認められ, 各患者の最大疼痛時における IM スプレーによる痛 みのスケールの変化を求めた結果 $($ mean $\pm \mathrm{SE}, n=$ 5), 噴霧前の $3.4 \pm 0.2$ から噴霧後の $1.8 \pm 0.2$, 平均で 1.6 の疼痛の軽減が見られた。使用回数は 1 日 4-10 回程度で, スプレー 1 本 $(10 \mathrm{ml})$ を 3-7 日間で使い切った。全体的に痛みに比例して使用量 が増加し, 口内炎の治癒とともに使用頻度は減少す る傾向にあった。 IM スプレー使用時の味や使用感 については，患者から特に不快感などの訴えはなか つた。また，特に副作用や臨床検査值への影響は認 められなかった.

4. 塩酸モルヒネの使用量の変化 IM スプ レ一使用群 9 名と未使用群 10 名における移植後の 1 日当たりの塩酸モルヒネ注射薬の使用量の経時変 化を調べた結果（Fig. 7)，全体的な使用量の減少 が認められ，1 日の平均最高使用量は IM スプレー 未使用群の移植後 10 日目の $45.0 \pm 4.9 \mathrm{mg}$ から, 使 用群の 11 日目の $22.4 \pm 3.8 \mathrm{mg}$ へほぼ半分となつ た。移植患者 1 名当たりの総使用量 $($ mean $\pm \mathrm{SE})$

は, IM 未使用患者 $418 \pm 50 \mathrm{mg}(n=10)$, IM 使用 患者で $220 \pm 47 \mathrm{mg}(n=9)$ で, 有意な減少が見ら れた $(p<0.05)$.

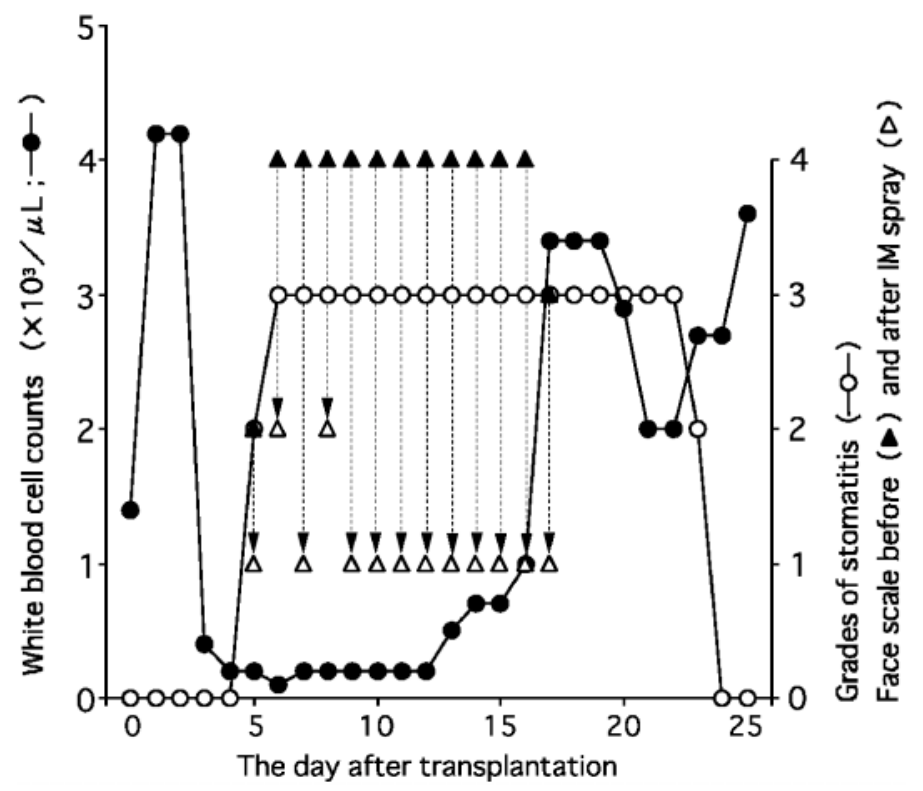

Fig. 6. The Change of Pain Scores of Stomatitis before ( $\boldsymbol{\Delta})$, after Spraying Indomethacin (IM) Solution ( $\triangle$ ), Time Courses of Grades of Stomatitis $(\bigcirc)$, and White Blood Cell (WBC) Counts $(\mathbf{O})$ for a Patient of Hematopoietic Stem Cell Transplantation (man, 46 years) 


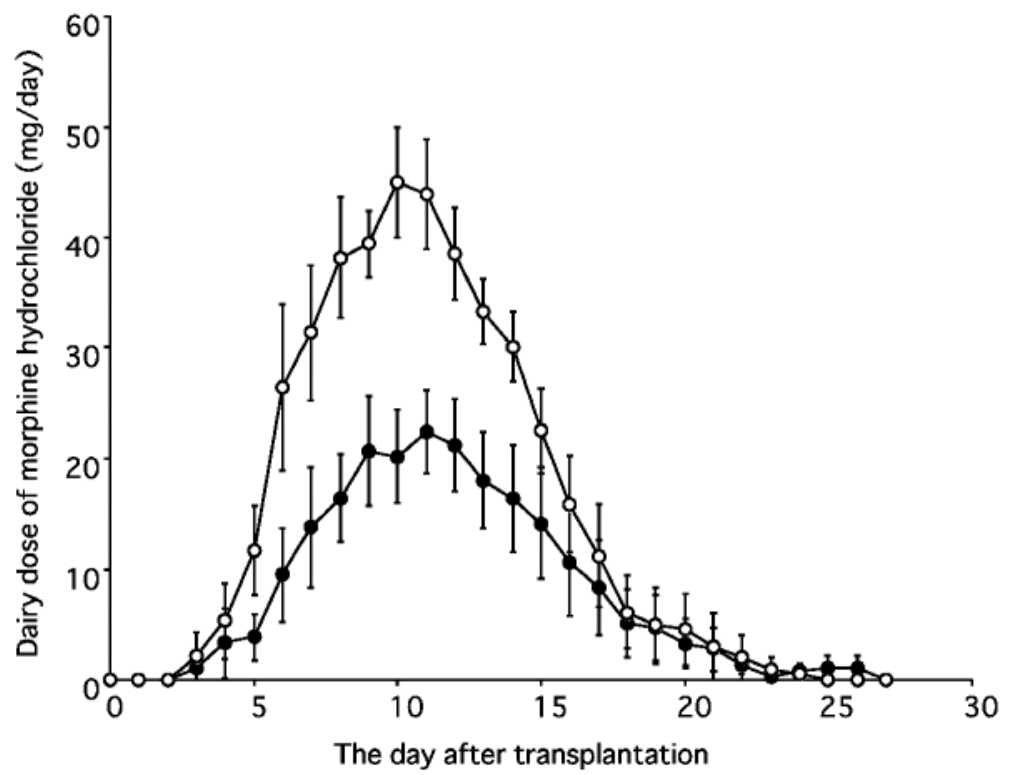

Fig. 7. Time Courses of Daily Dose of Morphine Hydrochloride in Patients for Blood Stem Cell Transplantation with without Use of Indomethacin (IM) Spray (O)

考

察

癌化学療法時における口内炎は，抗悪性腫瘍剂が フリーラジカルを発生させて口腔粘膜の細胞を直接 的に破壊する作用と，薬剤による骨髄抑制による白 血球減少により口腔内の局所感染が原因となる. 特 に, 造血幹細胞移植の場合では, 放射線全身照射と 大量化学療法により骨骾機能をほぼ完全に破壊する ため, 血中の $\mathrm{WBC}$ 数は移植後数日で $0.1 \times 10^{3} / \mu \mathrm{L}$ 以下になり, 造血幹細胞移植患者のほぼすべてに重 篤な口内炎が発症する。この口内炎は造血幹細胞が 生着し, WBC 数の増加とともに治癒するが, 激し い疼痛を伴うため患者の QOL は大きく低下する. 本研究において実施した患者群においても，WBC 数の減少に伴う口内炎の発症がすべての症例で認め られ，その程度は grade 2 を超える時期が約 1 週間 続いた (Fig. 4). WBC 数と口内炎の程度の関係に おいて時計回りのヒステリシスが認められたのは, $\mathrm{WBC}$ 数の減少により 2 次的に口腔内での細菌抵抗 性が減少し，その後口内炎に移行するという段階を 経ているためと考えられる（Fig. 5).

口内炎の発症に伴い発生する疼痛を軽減するため に多くの施設で種々の試みがなされている. 当院に おいても, 局所麻酔薬の塩酸プロカインと抗炎症薬 のアズレンの含嗽液を使用しているが，患者からの
疼痛の訴えは少なくなく，その効果は不十分である と言える。そのため, 疼痛が激しい時期には塩酸モ ルヒネの持続静脈内投与によって疼痛を抑えてい る.さらに，当院では患者が疼痛を感じた時に患者 自身で簡便に痛みをコントロールできる方法として IM スプレーの使用を開始しており患者からの好感 触を得ているが，定量的な解析については未だなさ れていない. 本研究では 9 名の移植患者において,

IM 使用前後の痛みを連日, 我々が口内炎用に作成 したフェイススケールを用いて患者自身が判定し た. 口内炎が発生する時期は患者の状態が不安定で 発熱や不快感により患者が最も辛い時期であるため, 4 名の患者では IM スプレーは使用したものの痛み のデータはとれなかった。残りの 5 名のうち IM ス プレー使用前後の痛みを記載した 1 名（男性, Fig. 6）では，使用期間中の連日，使用後の痛みの軽減 が見られ，IM スプレーの効果が認められた。 5 名 の患者の最大疼痛時における IM スプレー使用前後 の痛みのスケールにおいても平均で 3.4 から 1.6 ま で軽減し, 患者にとって痛みから大幅に解放された と考えられる. その理由としては, 従来は口内炎疼 痛にほとんど使用されてない非ステロイド性鎮痛薬 を使用したこと，口内炎の患部のみに局所的に作用 させることで高濃度の液を使用できたことにより効 果が強く発現したと思われる。 また, 繁用される局 
所麻酔薬の含嗽が短時間で効果がなくなるのに対 し，本スプレーの作用が 4-5 時間持続する理由は 今のところ不明であるが，IM の組織との親和性が 関与している可能性が考えられる.

疼痛の軽減に使用されている塩酸モルヒネの使用 量は，IM スプレ一使用時期全般に渡って激減し (Fig. 7)，IM スプレーの効果が明らかに発現して いることが示された，塩酸モルヒネは，患者が口内 炎疼痛に耐えられなくなった時に使用するが，その 投与量を増量しなくても疼痛のコントロールが可能 になったと言える。

味や使用感においては特に患者からの訴えはな く, 問題はないことが示されている. また，噴霧さ れた薬液中の IM は最終的に消化管から吸収される か又は口腔粘膜から吸収されると考えられるが， IM スプレー 1 噴霧で IM 約 $0.2 \mathrm{mg}, 1$ 本 $10 \mathrm{~mL}$ （約 120 噴霧分）においても経口薬 1 カプセル（25 $\mathrm{mg}$ ）分であり，監用しなければ全身的副作用の発 現はないと考えられ，安全性も高い製剂と思われる。

Shiratsuchi らの固形癌における化学療法時の口 内炎痛に対する IM スプレーの検討6)では, 疼痛の 評価を visual analogue scale を用いて行っている が，使用前のスコア 8 -9 から，使用後 $10 \min$ の 0 一2へ，劇的な効果が認められている. また持続時 間は 2-6 時間であり, また, 患部への刺激性に関 しては，特に問題はなかったが，我々が使用してい ない原液（1.25\%）を使用した場合に滲みる刺激が あるとしている，このことから，今回の我々の結果 は傾向としては Shiratsuchi らの報告と同様である と言える.

以上のことから， IM スプレーは，造血幹細胞移 植患者における口内炎疼痛を軽減するうえで有用で あり，また痛い時に患者自身で即座に対応できるこ とから非常に便利な製剤であることが示された。
IM スプレーの口内炎痛への適用は造血幹細胞移植 患者の QOL 向上に大きく貢献するものと考える.

謝辞本研究にあたり, IM 溶液の粘度の測定 に御協力いただきました東京理科大学薬学部石坂隆 史博士に感謝いたします。

\section{REFERENCES}

1) "New Trends in Hematopoietic Stem Cell Transplantation," eds. by Harada M., Kato S., Sonoda Y., Nanko-do, Tokyo, 1998.

2) Sonis S. T., Oral Oncology, 34, 39-43 (1998).

3) Yana N., Muroi M., Cho M., Otani T., Yoshigami Y., Nakamura J., Shinzaki N., Sakagami Y., Jpn. J. Hosp. Pharm., 18, 510515 (1992).

4) Yasuno N., Watanabe S., Kanda S., Kizu J., Tsuchiya M., Nishitani A., Ono H., Imai K., Ishio K., Iinuma T., Jpn. J. Hosp. Pharm., 21, 327-334 (1995).

5) "Martindale, The Complete Drug Reference," 33 ed. by Sweetmann S. C., Pharmaceutical Press, 2002, pp. 44-47.

6) Shiratsuchi T., Makimura M., Furukawa T., Miwa H., Takezawa M., Kan Y., Jpn. J. Clin. Res. Death Dying, 23, 98-103 (2000).

7) Chiba K., Takahashi M., Hayase N., Akutsu S., Inagaki S., Iyaku J., 26, 1173-1178 (1990) .

8) Yamamoto N., "Adverse Effects of Chemotherapy for Cancer and the Counterplan," ed. by Saijo N., Chugai-Igakusha, Tokyo, 1998, p. 93.

9) "Guideline for Treatment of Cancer Pain," ed. by Japan Society for Palliative Medicine, Shinkoukoueki-isho-shuppanbu, Tokyo, 2000, p. 16. 